\title{
Preliminary study of community-acquired Staphylococcus aureus infection in Manaus Hospital, Amazonia Region, Brazil
}

\author{
Estudo preliminar das infeccões por Staphylococas aureus na comunidade \\ de um Hospital em Manaus, Regiâo do Amazonas, Brasil
}

Jesus M. Egido ${ }^{1}$ and Marcus L. Barros ${ }^{1}$

\begin{abstract}
Methicillin resistant Staphylococcus aureus is considered a public health problem with a strong potential for dissemination and high rates of morbidity and mortality. In this study we describe bacteriological and epidemiological characteristics of Staphylococcus aureus in Manaus (Amazon region). During the one-year study period (2000-2001), sixteen cases of acute pyogenic multiple abscess were evaluated. Community-acquired $\mathrm{S}$. aureus was identified as causative agent in 10 (62.5\%) patients. The strains tested with antimicrobials by discs diffusion method, exhibited a high rate of sensitivity to cephalexin (100\%), erythromycin (90\%). Oxacillinsusceptible Staphylococcus aureus was $90 \%$. No isolate was resistant to Vancomycin. To our knowledge, no series of community-acquired Staphylococcus aureus in Manaus hospital has been published. Our partial results showed a high rate of antimicrobial sensitivity among community-acquired Staphylococcus aureus in the hospital of Tropical Medicine Institute of Manaus, Amazon Region.
\end{abstract}

Key-words: Community-acquired Staphylococcus aureus. Methicillin resistant. Manaus hospital.

Resumo O Staphylococcus aureus resistente a meticilina é considerado como um problema na saúde publica por seu grande potencial de disseminação e altas porcentagens de morbidade e mortalidade. No estudo descrevemos as características bacteriológicas e epidemiológicas do Staphylococcus aureus na cidade de Manaus. No período de um ano (2000-2001) avaliou-se dezesseis casos de abscessos piogênicos múltiplos. Em 10 (62,5\%) doentes o agente causal foi identificado como Staphylococcus aureus adquirido na comunidade $O$ estudo das bacterias isoladas frente aos diferentes antimicrobianos, seguindo o método de difusão em disco, mostrou boa sensibilidade a cefalexina (100\%) e eritromicina (90\%). Noventa porcento dos Staphylococcus aureus isolados foram sensíveis ao oxacilina. Nenhum dos isolados mostrou ser resistente a Vancomicina. Não temos informações sobre publicações dos Staphylococcus aureus adquiridos na comunidade em hospitais de Manaus. Nossos resultados parciais mostram uma alta sensibilidade dos Staphylococcus aureus adquiridos na comunidade aos antimicrobianos, em pacientes internados no Instituto de Medicina Tropical do Manaus, na Região da Amazônia brasileira.

Palavras-chaves: Staphylococcus aureus adquirido na comunidade. Resistência a meticilina. Hospitais de Manaus.

Oxacillin-resistant Staphylococcus aureus (ORSA) infection and vancomycin-resistant Staphylococcus aureus (VRSA) infection are an important cause of hospital morbidity and mortality. We report sixteen isolations of Gram positives rods of patients who showed clinical symptomatology of infections and received hospital treatment. The bacteriological isolates were identified. We found ten isolations of Staphylococcus aureus. These strains were tested against 12 different antimicrobial agents by standardized discs diffusion. They showed highest rates of sensitivity to cephalexin, erythromycin and oxacillin. The sixty percent of patients with Staphylococcus aureus infection, described in this report, were initially treated empirically with oxacillin. All patients recovered completely.

\footnotetext{
1. Clínica de Infectologia Médica da Fundação de Medicina Tropical do Amazonas, Manaus, AM, Brasil

Address to: Dr. Jesus M. Egido. FMTAM. Av. Pedro Teixeira 25. 69040-000 Manaus, AM. Brazil.

e-mail: egido@medscape.com

Recebido para publicação em 24/9/2002

Aceito em 28/8/2003
} 


\section{MATERIAL AND METHODS}

Samples were taken by aseptic needle abscess aspiration in order to avoid bacteriological contamination. In vitro susceptibility testing was performed by the Kirby and Bauer standardized disc diffusion method as described by the National Committee for Clinical Laboratory Standards (NCCLS). We used bacteriological probes to identify the etiologic agents. Specific Methicillin sensitivity test was not performed.

\section{RESULTS}

Etiologic agents were identified as: Staphylococcus aureus in $10(62.5 \%)$ cases, Staphylococcus epidermidis $4(25 \%)$ and Streptococcus sp $2(12.5 \%)$. The age range was one year to 49 years (mean 23 years). Sex distribution frequency was $56.3 \%$ for men and $43.8 \%$ for women.

The distribution of the Staphylococcus aureus infection isolates, were mainly leg abscesses $(40 \%)$. Multiple body abscesses were found in $30 \%$ of cases.
The antimicrobial agents that showed the highest in vitro activity were cephalexin (100\%), erythromycin (90\%), oxacillin (90\%), gentamicin (90\%) and ceftriaxone (85\%). Intermediate antimicrobial activity was demonstrated by clindamycin $(75 \%)$ and cefoxitin $(70 \%)$ and low antimicrobial activity by ampicillin $(50 \%)$, penicillin $(30 \%)$, trimethoprim-sulfamethoxazole (30\%) and tetracycline $(25 \%)$. All isolates were vancomycin-susceptible. All sixty percent of staphylococcal infections received initial empirical oxacillin treatment.

\section{DISCUSSION}

In a review of medical records of Methicillin resistant Staphylococcus aureus (MRSA) in community isolates we found a different prevalence. Alghaithy and cols ${ }^{2}$ in Saudi Arabia reported a $25.4 \%$ $(299 / 76)$ MRSA in community health isolates and $26.1 \%$ among healthy hospital??Não faz sentido, talvez deve ser "among isolates from hospitals". In New Zealand, Gosbell and cols ${ }^{4}$ found a 29\% (122/36) MRSA in community-acquired isolates. Akiyama and cols $^{1}$ in Japan found a $27 \%(130 / 35)$ MRSA in strains from skin clinics. In USA, Groom and cols ${ }^{5}$ in an American Indian community found 55\% (112/62) MRSA in community-acquired infection and Naimi and cols ${ }^{6}$ in Minnesota found more than $90 \%$ of isolates were susceptible to all antimicrobial agents tested, with the exception of beta-lactams and erythromycin.

Brazilian data showed a high prevalence of MRSA. In Rio de Janeiro, Loureiro and cols ${ }^{7}$ found a $47.8 \%$ (90/43) MRSA isolated from nasal swabs of newborns. In other sources of Staphylococcus aureus infection, in São Paulo, Costa and cols ${ }^{3}$ showed, in strain test by standardized disc diffusion method, that $84.4 \%$ were resistant to ampicillin and penicillin and a high sensitivity to cephalothin $(84.4 \%)$ and gentamicin $(80 \%)$ in strains isolated from mammary parenchyma.

Our results showed a high rate of antimicrobial sensitive to the first generation of cephalosporins (cephalexin) and macrolides (erythromycin) and low rates to penicillins (penicillin, ampicillin). Only one strain was ORSA and no isolate presented VRSA. Normally, in Manaus area, the diagnosis of clinical staphylococci infections is very common. Bacteriological probes are expensive and slow. Consequently, such cases are treated empirically with oxacillin.

In this preliminary study, we found a high rates of antimicrobial sensitivity in Staphylococcus aureus community-acquired isolates compared with other reports. We propose that empirical antimicrobial treatment for these patients should be carefully designed in order not to promote antimicrobial resistance. Cephalosporins could be the first choice in the treatment of clinical or community staphylococcal infection in Manaus hospital. Further studies and laboratory tests should be performed.

\section{REFERENCES}

1. Akiyama H, Yamasaki $O$, Tada J, Arata J. Adherence characteristics and susceptibility to antimicrobial agents of Staphylococcus aureus strains isolated from skin infections and atopic dermatitis. Journal of Dermatology Science 23:155-160, 2000.

2. Alghaithy AA, Bilal NE, Gedebou M, Weily AH. Nasal carriage and antibiotic resistance of Staphylococcus aureus isolates from hospital and non-hospital personnel in Abha, Saudi Arabia. Transaction Royal Society of Tropical Medicine and Hygiene 94:504-507, 2000

3. Costa EO, Benites NR, Guerra JL, Melville PA. Antimicrobial susceptibility of Staphylococcus spp. Isolated from mammary parenchyma's of slaughtered dairy cows. Journal of Veterinary
Medicine of Cows and Infectious Disease and Veterinary Public Health 47:99-103, 2000.

4. Gosbell IB, Mercer JL, Neville SA, Crone SA, Chant KG, Jalaludin BB, Munro R. Non-multiresistant and multiresistant methicillinresistant Staphylococcus aureus in community-acquired infections. Medical Journal of Australia 174:627-630, 2001.

5. Groom AV, Wosley DH, Naimi TS, Smith K, Johnson S, Boxrud D, Moore KA, Cheek JE. Community-acquired methicillinresistant Staphylococcus aureus in a rural American Indian community. The Journal of American Medical Association 286:1201-1205, 2001.

6. Naimi TS, Le Dell KH, Boxrud DL, Groom AV, Steward CD, Johnson SK, Besser JM, O'Boyle C, Danila RN, Cheek JE, 
Osterholm MT, Moore KA, Smith KE. Epidemiology and clonality of community-acquired methicillin-resistant Staphylococcus aureus in Minnesota, 1996-1998. Clinical Infectious Disease 33:990-996, 2001.
7. Loureiro MM, De Moraes BA, Quadra MR, Pinheiro GS, Suffys PN Asensi MD. Molecular Epidemiology of methicillin resistant Staphylococcus aureus isolated from newborns in a hospital in Rio de Janeiro. Memórias do Instituto Oswaldo Cruz 95:777-782, 2000. 